\title{
Penghambatan Reaksi Maillard dari Ekstrak Buah Pisang Goroho Putih (Musa acuminata Colla) Sebagai Pencegahan Diabetes Mellitus
}

\author{
Randy Tampa'i* \\ Sekolah Tinggi Ilmu Kesehatan Trinita, Manado, 95115, Indonesia
}

INFO ARTIKEL

\begin{tabular}{l}
\hline Diterima 16 April 2019 \\
Disetujui 30 April 2019 \\
\hline Key word: \\
Maillard Reaction \\
Antioxidant \\
Musa acuminata Colla \\
\hline Kata kunci: \\
Reaksi Maillard \\
Antioksidan \\
Pisang Goroho Putih \\
\end{tabular}

\begin{abstract}
A B S T R A C T
Indonesian natural products that are antioxidant have diversity and have not been used optimally, one of which is white goroho banana. White goroho banana (Musa acuminate Colla) is one of the endemic plants originating from North Sulawesi. These bananas are often used empirically as an additional / main food for people suffering from diabetes mellitus. This research aims to determine the potential inhibition of the Maillard reaction from extracts of white goroho banana by measuring the carbonyl protein content using a spectrophotometer. The result of this research is white goroho banana can used as inhibitor Maillard reaction to restrain Diabetes mellitus surface and grow. Acetone extract has the highest inhibitor Maillard reaction than ethanol and methanol. The activity of inhibitor Maillard reaction from acetone, ethanol and methanol extracts are 5,49; 3,$18 ; 2,96 \%$.
\end{abstract}

\section{A B S T R A K}

Produk alam Indonesia yang bersifat antioksidan sangatlah berlimpah dan belum dimanfaatkan secara optimal, salah satunya adalah pisang goroho putih (Musa acuminata Colla). Pisang goroho putih (Musa acuminate Colla) merupakan salah satu tanaman endemik yang berasal dari Sulawesi Utara. Pisang ini sering digunakan secara empiris sebagai makanan tambahan/ pokok bagi orang yang menderita penyakit diabetes mellitus. Penelitian ini bertujuan untuk menentukan potensi penghambatan reaksi Maillard dari ekstrak buah pisang goroho putih dengan mengukur kandungan protein karbonil menggunakan spektrofotometer. Dari penelitian ini diperolah hasil bahwa ekstrak buah pisang goroho putih dapat berperan sebagai penghambat (inhibitor) reaksi Maillard untuk mencegah timbul dan berkembangnya penyakit diabetes mellitus. Ekstrak aseton memiliki aktivitas penghambat reaksi Maillard tertinggi dibandingkan ekstrak etanol dan metanol. Aktivitas penghambatan reaksi Maillard dari ekstrak aseton, etanol dan metanol berturut-turut adalah 5,49; 3,18; 2,96 \%.

\section{Pendahuluan}

Kereaktifan radikal bebas dapat menimbulkan berbagai penyakit degeneratif seperti diabetes mellitus. Peningkatan kadar glukosa dalam darah disebabkan oleh kerusakan pankreas sehingga tidak dapat 
menghasilkan insulin. Kerusakan pankreas ini disebabkan oleh peroksidasi lipid, yaitu kerusakan oksidatif pada biomolekul lipid akibat reaktivitas senyawa oksigen reaktif (SOR) [1]. Pengobatan diabetes saat ini dilakukan dengan mengkombinasikan antara antidiabetes dan antioksidan. Hal ini disebabkan obat antidiabetes tidak bekerja memperbaiki sel pankreas- $\beta$ yang rusak akibat radikal bebas, tetapi hanya menstimulasi pelepasan insulin dari sel pankreas- $\beta$ [2]. Selain itu, peningkatan suplai antioksidan yang cukup akan membantu pencegahan komplikasi klinis diabetes mellitus [3].

Produk alam Indonesia yang bersifat antioksidan sangatlah berlimpah dan belum dimanfaatkan secara optimal, salah satunya adalah pisang goroho. Pisang goroho (Musa acuminata) merupakan salah satu tanaman endemik yang berasal dari Sulawesi Utara. Pisang ini sering digunakan secara empiris sebagai makanan tambahan/pokok bagi orang yang menderita penyakit diabetes mellitus. Pisang goroho secara umum terdiri atas 2 jenis, yaitu pisang goroho putih dan pisang goroho merah, yang dikonsumsi baik dengan cara direbus maupun digoreng. Penelitian mengenai senyawa polifenol dan aktivitas antioksidan dari pisang goroho putih sudah dilakukan sebelumnya dan diketahui bahwa pisang goroho putih mengandung senyawa fenolik, flavonoid dan tannin, serta memiliki aktivitas sebagai antioksidan melalui uji aktivitas antioksidan DPPH [4].

Penelitian ini bertujuan untuk menentukan kemampuan penghambatan reaksi Maillard dari ekstrak buah pisang goroho putih dengan mengukur kandungan protein karbonil secara spektrofotometrik, untuk menentukan potensi dari ekstrak buah pisang goroho putih (Musa acuminata Colla) sebagai inhibitor reaksi Maillard yang dapat mencegah terbentuknya radikal bebas.

\section{Bahan dan Metode}

Sampel yang digunakan adalah buah pisang goroho putih yang belum matang, sedangkan alat dan bahan-bahan kimia yang dipakai dalam penelitian ini adalah: metanol, etanol 95\%, aseton, akuades, kertas saring whatman no. 42, shaker, centrifuge, rotary evaporator, oven, aluminium foil, erlenmeyer, lemari pendingin, spektrofotometer, BSA (Bovin Serum Albumin), putih telur, glukosa \& 2,4dinitrofenilhidrazin (DNPH).

Sampel pisang yang siap diekstrak, masing-masing ditimbang sebanyak 50 gram, lalu direndam selama 24 jam dalam $100 \mathrm{ml}$ pelarut (Metanol 90\%, Etanol 90\% dan Aseton 90\%). Setelah itu, masing-masing sampel dimasukkan ke dalam labu erlenmeyer, sampel kemudian dikocok (shake) dengan menggunakan shaker selama 2 jam. Setelah itu, sampel disentrifus selama 15 menit, lalu disaring menggunakan kertas saring Whatman No.42. Filtrat tersebut kemudian diuapkan menggunakan rotari evaporator pada suhu $40^{\circ} \mathrm{C}$. Setelah itu, sampel yang telah dievaporasi dimasukkan ke dalam labu erlenmeyer, dan ditambahkan metanol hingga volumenya cukup $100 \mathrm{ml}$. Ekstrak yang diperoleh disimpan dalam lemari pendingin sebelum dilakukan analisis dan pengujian.

Penentuan kemampuan penghambatan reaksi Maillard menggunakan metode Uchida yang dimodifikasi [5]. Prinsip dari reaksi ini adalah protein direaksikan dengan glukosa konsentrasi tinggi sebagai kontrol kinetika, sedangkan kontrol dinamika, reaksi dikendalikan pada suhu $37^{\circ} \mathrm{C}$ dengan pemanasan 2,5 jam. Kemampuan ekstrak pisang goroho putih dalam penghambatan reaksi Maillard merupakan indikator awal mencegah terjadinya penyakit diabetes mellitus. Sebanyak $0,5 \mathrm{ml}$ ekstrak pisang goroho (500 ppm), $500 \mu \mathrm{L}$ bovine serum albumin (BSA) $20 \%$, putih telur dan $0,5 \mathrm{ml}$ glukosa. Sampel dari campuran tersebut dimasukkan ke dalam botol serum yang berukuran $10 \mathrm{ml}$ yang dilengkapi dengan penutup karet dan aluminium foil. Botol tersebut kemudian diletakkan dan disimpan, diinkubasi dalam oven pada suhu $37^{\circ} \mathrm{C}$ selama 2,5 jam. Setelah itu $0,2 \mathrm{ml}$ sampel ditambah dengan $0,2 \mathrm{ml}$ 2,4dinitrofenilhidrazin (DNPH) 2,5 M, divorteks dan ditambahkan dengan $5 \mathrm{ml} \mathrm{HCl} \mathrm{2N}$, lalu disentrifus. Setelah itu, dibaca kandungan protein karbonil dengan spektrofotometer. Warna yang dihasilkan diukur serapannya pada panjang gelombang $390 \mathrm{~nm}$. Kerusakan protein dihitung dengan rumus: $\mathrm{C}=\mathrm{A} / \varepsilon \mathrm{b}$ dengan $\varepsilon=22000 \mathrm{~nm} / \mathrm{M}$. 


\section{Hasil dan Pembahasan}

Besar penghambatan reaksi Maillard dari ekstrak buah pisang goroho putih dapat dilihat pada Gambar 1.

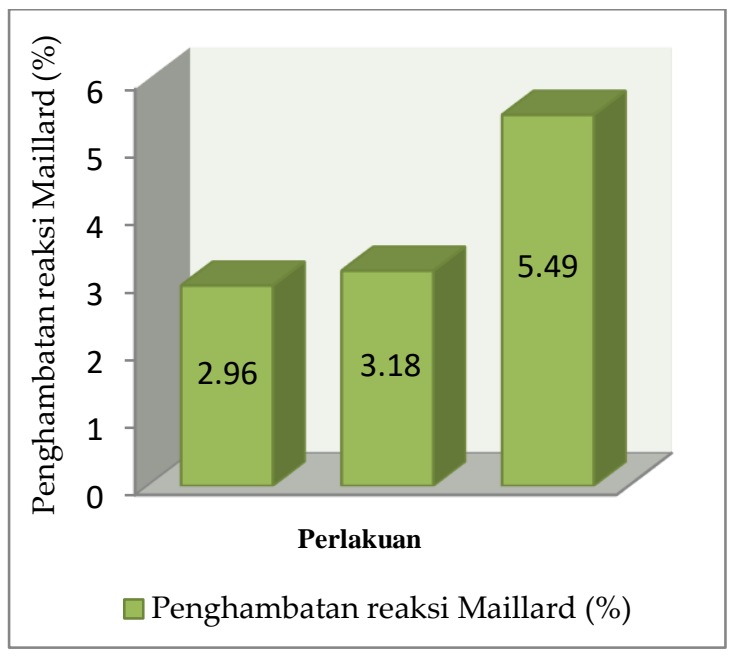

Gambar 1. Perbandingan antara persentase penghambatan reaksi Maillard dari ekstrak buah pisang goroho putih

Tabel 1. Data Penghambatan Reaksi Maillard dari Ekstrak Buah Pisang Goroho Putih dengan menggunakan Protein Putih Telur.

\begin{tabular}{|c|c|c|}
\hline Perlakuan & Absorbansi & $\begin{array}{c}\text { Kadar Senyawa } \\
\text { Dikarbonil } \\
(\mu \mathrm{M})\end{array}$ \\
\hline \multirow{2}{*}{ Putih Telur (PT) } & 0,181 & $8,23 \times 10^{-6}$ \\
\hline & 0,187 & $8,5 \times 10^{-6}$ \\
\hline \multicolumn{2}{|c|}{ Rata-rata } & $8,36 \times 10^{-6}$ \\
\hline \multirow{2}{*}{$\mathrm{PT}+\mathrm{Glu}$} & 0,2 & $9,09 \times 10^{-6}$ \\
\hline & 0,201 & $9,14 \times 10^{-6}$ \\
\hline \multicolumn{2}{|c|}{ Rata-rata } & $9,11 \times 10^{-6}$ \\
\hline \multirow{2}{*}{$\mathrm{PT}+\mathrm{Glu}+\mathrm{E} . \mathrm{M}$} & 0,192 & $8,73 \times 10^{-6}$ \\
\hline & 0,197 & $8,95 \times 10^{-6}$ \\
\hline \multicolumn{2}{|c|}{ Rata-rata } & $8,84 \times 10^{-6}$ \\
\hline \multirow{2}{*}{$\mathrm{PT}+\mathrm{Glu}+\mathrm{E} \cdot \mathrm{E}$} & 0,19 & $8,64 \times 10^{-6}$ \\
\hline & 0,198 & $9 \times 10^{-6}$ \\
\hline \multicolumn{2}{|c|}{ Rata-rata } & $8,82 \times 10^{-6}$ \\
\hline \multirow{2}{*}{$\mathrm{PT}+\mathrm{Glu}+\mathrm{A} . \mathrm{E}$} & 0,182 & $8,27 \times 10^{-6}$ \\
\hline & 0,197 & $8,95 \times 10^{-6}$ \\
\hline \multicolumn{2}{|c|}{ Rata-rata } & $8,61 \times 10^{-6}$ \\
\hline
\end{tabular}

Penghambatan reaksi Maillard dari buah pisang goroho putih dapat diketahui dengan menentukan besarnya kerusakan protein yang dapat diukur dengan menggunakan parameter kadar senyawa dikarbonil. Tingginya kadar senyawa dikarbonil, menunjukkan besarnya kerusakan protein [6].

Tabel 2. Data Penghambatan Reaksi Maillard dari Ekstrak Buah Pisang Goroho Putih dengan menggunakan Protein BSA

\begin{tabular}{|c|c|c|}
\hline Perlakuan & Absorbansi & $\begin{array}{c}\text { Kadar Senyawa } \\
\text { Dikarbonil } \\
(\mu \mathrm{M})\end{array}$ \\
\hline \multirow{2}{*}{ BSA } & 0.182 & $8.27 \times 10^{-6}$ \\
\hline & 0.194 & $8.82 \times 10^{-6}$ \\
\hline \multicolumn{2}{|c|}{ Rata-rata } & $8.54 \times 10^{-6}$ \\
\hline \multirow{2}{*}{ BSA + Glu } & 0.189 & $8.59 \times 10^{-6}$ \\
\hline & 0.218 & $9.91 \times 10^{-6}$ \\
\hline \multicolumn{2}{|c|}{ Rata-rata } & $9,25 \times 10^{-6}$ \\
\hline \multirow{2}{*}{$\mathrm{BSA}+\mathrm{Glu}+\mathrm{E} \cdot \mathrm{M}$} & 0.212 & $9.64 \times 10^{-6}$ \\
\hline & 0.28 & $12,72 \times 10^{-6}$ \\
\hline \multicolumn{2}{|c|}{ Rata-rata } & $11,18 \times 10^{-6}$ \\
\hline \multirow{2}{*}{$\mathrm{BSA}+\mathrm{Glu}+\mathrm{E} \cdot \mathrm{E}$} & 0.294 & $13,36 \times 10^{-6}$ \\
\hline & 0.291 & $13,23 \times 10^{-6}$ \\
\hline \multicolumn{2}{|c|}{ Rata-rata } & $13,29 \times 10^{-6}$ \\
\hline \multirow{2}{*}{$\mathrm{BSA}+\mathrm{Glu}+\mathrm{A} \cdot \mathrm{E}$} & 0.297 & $13,5 \times 10^{-6}$ \\
\hline & 0.281 & $12,77 \times 10^{-6}$ \\
\hline \multicolumn{2}{|c|}{ Rata-rata } & $13,14 \times 10^{-6}$ \\
\hline
\end{tabular}

Dari data yang diperoleh menunjukkan bahwa kadar senyawa dikarbonil $(\mu \mathrm{M})$ dari putih telur tanpa penambahan zat apapun adalah $8,36 \times 10^{-6} \mu \mathrm{M}$, pada penambahan glukosa sebesar 9,11 $\times \quad 10^{-6} \mu \mathrm{M}$, pada penambahan glukosa dan ekstrak metanol sampel sebesar $8,84 \quad X \quad 10^{-6} \mu \mathrm{M}$, pada penambahan glukosa dan ekstrak etanol dari sampel sebesar $8,82 \times 10^{-6} \mu \mathrm{M}$, dan pada penambahan glukosa dan ekstrak aseton dari sampel sebesar 8,61 X 10-6 $\mu \mathrm{M}$. Uji statistika menunjukkan besar penghambatan reaksi Maillard yang terjadi dari ketiga ekstrak buah pisang goroho putih (EM, EE dan EA), tidak 
berbeda nyata $(p<0,05)$ satu sama lain.

Dari hasil penelitian yang telah dilakukan, dapat disimpulkan bahwa terdapat perbedaan yang bermakna pada kadar senyawa dikarbonil diantara beberapa kelompok perlakuan tersebut. Dari data hasil penelitian, dapat diketahui bahwa kadar senyawa dikarbonil pada penambahan glukosa lebih besar dibandingkan dengan larutan putih telur tanpa adanya penambahan suatu zat. Hal ini menunjukkan bahwa putih telur yang ditambahkan glukosa memiliki kadar senyawa dikarbonil yang lebih tinggi secara bermakna dibandingkan dengan larutan putih telur tanpa diberikan glukosa. Sedangkan kadar senyawa dikarbonil pada penambahan glukosa dan ekstrak buah pisang goroho putih, lebih rendah dibandingkan kadar senyawa dikarbonil dengan penambahan glukosa. Terjadinya penurunan kadar senyawa dikarbonil ini diperankan oleh adanya penambahan ekstrak buah pisang goroho putih.

Selain itu, dari data hasil penelitian didapatkan adanya perbedaan kadar senyawa dikarbonil antara perlakuan yang menggunakan putih telur dan BSA $20 \%$. Dimana perlakuan dengan menggunakan putih telur sebagai protein dalam proses penghambatan reaksi Maillard memberikan hasil yang lebih baik dalam penurunan kadar senyawa dikarbonil setelah penambahan ekstrak. Hal ini dimungkinkan karena adanya perbedaan kandungan antara putih telur dan BSA, yang menyebabkan terjadinya perbedaan hasil penurunan kadar senyawa dikarbonil dalam proses penghambatan reaksi Maillard.

Walaupun demikian, dari hasil yang diperoleh dengan menggunakan putih telur menunjukkan adanya perbedaan kadar senyawa dikarbonil antara perlakuan sebelum ditambahkan ekstrak dan setelah ditambahkan ekstrak sampel, nilainya tidak terlalu berbeda secara signifikan. Ini diduga karena di dalam buah pisang goroho juga terkandung senyawa seperti karbohidrat, dextrosa dan levulosa yang merupakan gula sederhana. Gula sederhana yang terkandung dalam buah pisang goroho putih ini ikut mendukung terjadinya peningkatan kadar senyawa dikarbonil dalam uji penghambatan reaksi Maillard.

Jika dikaitkan hubungan antara penurunan kadar senyawa dikarbonil yang terjadi pada uji penghambatan reaksi Maillard dari buah pisang goroho putih dengan penyakit diabetes mellitus, dapat disimpulkan bahwa buah pisang goroho putih berfungsi untuk menghambat terjadinya reaksi Maillard yang nantinya akan menghasilkan produk senyawa radikal yang dapat menyebabkan penyakit diabetes mellitus. Buah pisang goroho putih ini memiliki potensi untuk mengurangi atau meminimalkan terjadinya pembentukan reaksi Maillard dalam tubuh. Ini dikarenakan dalam buah pisang goroho putih terdapat beberapa senyawa bioaktif seperti polifenol, flavonoid dan tannin yang berperan sebagai antioksidan untuk mencegah serta mengurangi terjadinya pembentukan produk senyawa radikal hasil dari reaksi Maillard yang nantinya dapat merusak sel dan jaringan tubuh, terutama kerusakan pada sel pankreas $\beta$ yang merupakan faktor utama terjadinya penyakit diabetes mellitus tipe I [7]. Suplai antioksidan dari buah pisang goroho putih ini juga dapat membantu mencegah terjadinya komplikasi klinis pada penyakit diabetes melitus.

Dari kombinasi inilah dapat dinyatakan bahwa buah pisang goroho putih dapat digunakan sebagai salah satu makanan alternatif yang cocok bagi penderita diabetes mellitus karena berfungsi preventif, yaitu untuk mencegah timbul dan berkembangnya penyakit diabetes mellitus.

\section{Ucapan terimakasih}

Selaku peneliti, saya ingin mengucapkan terimakasih untuk rekan-rekan dosen farmasi di STIKES Trinita Manado yang sudah mensupport dan memberikan masukan serta saran sehingga penelitian ini dapat terlaksana. Serta ungkapan terimakasih juga disampaikan untuk tenaga teknis laboratorium dan laboran di laboratorium farmasi STIKES Trinita yang sudah berpartisipasi dalam membantu jalannya penelitian.

\section{Kesimpulan}

Dari hasil penelitian, ekstrak buah pisang goroho putih (Musa acuminata Colla) dapat berperan sebagai penghambat (inhibitor) reaksi Maillard. Dari penelitian ini juga dapat dinyatakan bahwa buah pisang goroho putih 
dapat digunakan sebagai salah satu makanan alternatif yang cocok bagi penderita diabetes mellitus karena berfungsi preventif, yaitu dapat mencegah timbul dan berkembangnya penyakit diabetes mellitus. Ekstrak aseton memiliki aktivitas penghambat reaksi Maillard tertinggi dibandingkan ekstrak etanol dan metanol. Aktivitas penghambatan reaksi Maillard dari ekstrak aseton, etanol dan metanol dari buah pisang goroho putih berturut-turut adalah 5,49; 3,$18 ; 2,96 \%$.

\section{Daftar Pustaka}

1. Kumalaningsih, S., Antioksidan alami: penangkal radikal bebas. Trubus Agrisarana: 2006.

2. Adnyana, I. K.; Yulinah, E.; Soemardji, A. A.; Kumolosasi, E.; Iwo, M.; Sigit, J., Uji Aktivitas Antidiabetes Ekstrak Etanol Buah Mengkudu (Morinda citrifolia L.). Acta Pharmaceutica Indonesia 2004, 29, (2), 43-48.

3. D'adamo, P.; Whitney, C., Penemuan baru memerangi diabetes melalui diet golongan darah. Yogyakarta, PT Bentang Pustaka 2009.

4. Tampa'i, R.; Montolalu, M., Potensi Senyawa Polifenol dari Buah Pisang Goroho Putih (Musa acuminate Colla) sebagai antioksidan alami. In Seminar Nasional Biologi, Universitas Diponegoro: Semarang, 2018.

5. Uchida, K.; Kanematsu, M.; Sakai, K.; Matsuda, T.; Hattori, N.; Mizuno, Y.; Suzuki, D.; Miyata, T.; Noguchi, N.; Niki, E., Protein-bound acrolein: potential markers for oxidative stress. Proceedings of the National Academy of Sciences 1998, 95, (9), 4882-4887.

6. Sadikin, M.; Adhiyanto, C., Pengukuran konsentrasi senyawa dikarbonil. Disampaikan pada Pelatihan Radikal Bebas dan Antioksidan dalam Kesehatan: Dasar, Aplikasi, dan Pemanfaatan Bahan Alam, Jakarta 2001.

7. Meda, A.; Lamien, C. E.; Romito, M.; Millogo, J.; Nacoulma, O. G., Determination of the total phenolic, flavonoid and proline contents in Burkina Fasan honey, as well as their radical scavenging activity. Food chemistry 2005, 91, (3), 571-577. 